\title{
O GRANDE COMÉRCIO DE VINHO NA IDADE MÉDIA (1)
}

E' a vinha, por excelência, uma planta dos países de clima mediterrâneo: suas longas raízes não lhe fazem temer a sêca; os quentes estios amadurecem seus frutos. Prospera nas regiões meridionais da Europa e em todo o contôrno da bacia do Mediterrâneo. Aí chega, cresce, amadurece espontâneamente seus frutos; para repetir as felizes expressões de $\mathbf{R}$. Dion, aí existe uma viticultura primordial que está em perfeito acôrdo com o meio natural; nessas condiçóes, tem o homem a certeza de obter, com o mínimo de esfôrço, os mais certos resultados. Era essa a viticultura dos antigos, tanto dos judeus como dos gregos e romanos: obtinham, freqüentemente, um vinho grosso, ao qual juntavam água, em vasos, a fim de diluí-lo antes de beber. Tal vinho, sob essa forma concentrada, podia conservar-se mais fàcilmente; guardavam-no por vários anos e estimavam-no mais quando velho: Horácio cantá o falerno de quatro anos. Mas os romanos ricos, ainda no primeiro século, preferiam aos vinhos itálicos os vinhos exóticos: os vinhos da Síria, exportados por Gaza, os vinhos gregos de Quios e de Lesbos, e até os vinhos da Magna Grécia e da Sicília, que se assemelhavam aos vinhos gregos. Importavam, pois, vinhos de qualidade.

Essa bebida natural do ambiente mediterrâneo foi ìntimamente ligada às crenças e aos ritos das religiōes que nasceram no contôrno do Mediterrâneo: um deus, Dionísio, ou Baco, tem como atributos a vinha e o vinho, e é considerado como distribuidor de alegria; atribui-se poder profético à embriaguez das Ménades que - acompanham; e, aos poucos, nos mistérios dionisíacos, é o vinho considerado como bebida de eternidade: fazem-se reuniões para consumí-lo conjuntamente nos banquetes místicos de iniciados dos quais muitos mosaicos conservaram a decoração. Paralelamente, a Bíblia, desđe a história de Noé, encerra numerosas alusões à vinha e ao vinho; e quando Jesús institui a religião cristã, é o vinho o símbolo do sangue divino com o qual os discipulos comungam na Ceia; o sacrifício da missa reproduz, desde então, com os mesmos símbolos necessários, pão e vinho, essa refeição divina.

(1). - Tradução, devidamente autorizada, de artigo estampado na "Revue Historique de Bordeaux et du Departement de la Gironde", 1952, de grande interêsse para os nossos alunos, pois contém uma admirável síntese do comércio de um dos produtos de maior importância na Idade Média. ( $E$. Simões de Paula). 
Ao sul dessa zona mediterrânea tão naturalmente propícia à vinha, estende-se, na África e na Ásia, a faixa desértica em que a sêca impede a vegetação e a vida humana. Ao norte, na Europa, encontra-se, ao contrário, uma zona menos ensolarada, mais chuvosa, mais úmida, em que gela durante o inverno. Seu clima é menos favorável ao crescimento da vinha e à maturação da uva, mas pode permití-los, entretanto, em boas condições, contanto que o homem tenha para com a planta e seu fruto constantes cuidados: escolha de cêpas que resistam à geada, escolha do solo e da exposição, luta contra as moléstias causadas pela umidade, colheita atenta da uva, conservação do vinho em temperaturas tão iguais quanto pcssível, em armazéns ou adegas, segundo o rigor dos invernos. Essa segunda zona estende-se em latitude, conforme mostrou Dion (2), dos países mediterrâneos aos países vizinhos da Mancha e do Mar do Norte.

A partir dêsses últimos países estende-se, em direção ao norte, uma terceira zona, que abrange a Normandia, os Países-Baixos, a Inglaterra. A insuficiência de insolação, a excessiva umidade e as fortes geadas tornam a cultura da vinha muito incerta: a planta se ressente; a maturação da uva não é regular; as perdas consideráveis diminuem a produção, e o vinho é de qualidade muito medíocre, o mais das vêzes acídulo, ou francamente ácido.

Foram os romanos que, após suas conquistas, introduziram a cultura da vinha nessas duas zonas setentrionais, uma, mediocremente favorável, e a outra, pouco. O hábito que tinham de consumir vinho tornava-o necessário para êles; procuravam obtê-lo por tôda a parte; Dion mostrou que as vinhas da Gália Cisalpina thes ofereciam espécies que resistiam à geada, como a alobrógica, que plantaram nos arredores de Lyon e de Vienne, às margens do Ródano, ou que resistiam à umidade, como a bitúrica (vazadura), que prospera na Borgonha ou na Aquitânia, desde o primeiro século após Jesús Cristo. Fundaram quase que simultâneamente nesse século, ao que parece, os vinhedos de Rioja, na Espanha, os da Gasconha ou da Aquitânia, do Auvergne e da Borgonha, na França, e plantaram algumas vinhas em regiões mais setentrionais. $\mathbf{O}$ cristianismo, que, a partir do segundo século, se desenvolve no mundo do Ocidente, reforçou ainda mais essa tendência: o vinho é necessário à celebração da missa, rito central de uma religião que nasceu na região em que êle é a bebida dominante. A difusão do cristianismo nos países setentrionais, impondo aos padres a necessidade do vinho, levou-os a plantar vinhas nas regióes e nas épocas em que não tinham a certeza de abastecimento regular. $O$ monaquismo beneditino, que se espalhou nos países setentrionais a partir do nono século, admitia o consumo de vinho e tendeu a

(2). - R. Dion, "Grands traits d'une géographie viticole de 1a France", em Publications de la Société de Géographie de Lille, 1943, ps.'3-67; 1948-1949, ps. 6-46. 
introduzi-lo por tôda a parte em que o mesmo se estabeleceu. E' esta uma das mais nitidas manifestações da influência da religião sôbre as produções de um país: o cristianismo contribuiu fortemente para o desenvolvimento da cultura da vinha em países setentrionais em que ela se adaptava mais ou menos bem, e, às vêzes, nada. E, por contraste, para acentuar a mesma influência, a expansão do Islão na Síria e na África Setentrional, no VII século, aí abolia a viticultura, que, entretanto, convinha de modo tão perfeito a países em que a vinha crescia espontâneamente. O mapa da viticultura confunde-se, no VII século, com os dos impérios cristãos, do Oriente e do Ocidente; inclui até mesmo a Inglaterra, exterior ao império de Carlos Magno, ao passo que o desaparecimento da vinificação, senão da viticultura, na Síria - pois os muçulmanos muito apreciam a uva - aboliu o comércio do vinho de Gaza, que o Ocidente ainda consumia, na época merovíngia.

O progressivo desenvolvimento do consumo de vinho nos países setentrionais que a êle não estavam predispostos, pois a vinha não se encontrava neles em estado natural, resulta de duas necessidades fundamentais. A primeira é a necessidade de um tônico para se resistir ao clima frio e úmido; ora, o vinho, contendo mais álcool que a cerveja ou o hidromel, é o melhor tônico que se conheceu, ao qual se juntavam, talvez, algumas especiarias, no fim da Antiguidade e durante tôda a Idade Média; desconheciam-se todos os nossos tônicos modernos, o álcool, o café, o chá; trazidos por gente do Mediterrâneo, o gôsto e a necessidade do vinho desenvolveram-se naturalmente nas regiões do Norte. A segunda necessidade é de ordem litúrgica, essencial e decisiva, à medida que se desenvolvia o cristianismo nos países setentrionais, do VII ao XI século. E' preciso, também, acrescentar uma espécie de mcda: o vinho se impôs ainda mais por ser a bebida dos conquistadores, os romanos, e, depois, da classe dirigente, dos bispos e clérigos, sendo que a uns e outros se procura imitar. Por isso, os homens que, por diversas razões, por espírito de associação muitas vêzes matizado de certo misticismo, constituem agrupamentos, as hansas, bebem juntamente vinho: a compotacio vini constitui elemento fundamental das reuniões no cristianismo, sem que se apaguem, talvez, os mais antigos traços dionisíacos, nem a idéia de se assegurar a eternidade; origina-se, pois, da necessidade de se refazer, de se ganhar novas fôrças em comum.

O problema consistia, pois, em obter-se vinho nos países setentrionais, os da terceira zona, em que as condições naturais não eram favoráveis à vinha.

No decorrer da conquista, os vinhos necessários eram importados da Itália. Não tardou, porém, que o desenvolvimento dos vinhedos da Gália e da Espanha, plantados pelos romanos, permitisse o fornecimento do excedente de sua produção aos países setentrionais, Bretanha e Alemanha; a proximidade dêsse mercado muito 
contribuiu para o desenvolvimento dos vinhedos gauleses, cujo progresso se firmou desde o terceiro século, ao passo que os vinhedos italianos atravessam grande crise em suas exportações, conse-' qüencia dêsse progresso concorrente.

No período que corresponde à série de invasões que transtornaram constantemente o Ocidente do IV ao $X$ século, a gente das regiões setentrionais, Países-Baixos, Inglaterra, procurava obter vinho nos mercados da zona mediana que mais perto dela se achavam; as abadias das regiões belgas adquiriam plantações de vinha no vale do Reno, no do Moselle, no Laonnais, no Soisonnais; os que viviam na costa do Mar do Norte e os inglêses iam, na medida do possivel, comprar vinhos na feira do Lendit ou nas regiões do BaixoSena, em Ruão, para onde iam e de onde voltavam por barco. Os transportes eram relativamente fáceis, pois o emprêgo do admirável instrumento aue é o tonel de madeira, conhecido desde o tempo dos galo-romanos, que talvez o tenham inventado, suplantou $\circ$ das ânforas antigas, frágeis, de difícil manejo e de menor capacidade. Muitas vêzes, porém, tinham que contentar-se, evidentemente, com o vinho ácido das vinhas que haviam plantado em volta dos mosteiros e dos palácios episcopais, tanto nos Países-Baixos como na Inglaterra, pois as comunicações eram, por vêzes, impossíveis, e as trocas se rarefaziam.

Quando, porém, após o período das invasões, a partir do século XI, as trocas recomeçaram aos poucos, os habitantes dos países setentrionais da Europa, descontentes com seus vinhos, que, como diz Pierre de Blois acêrca dos vinhos inglêses do século XII, era preciso beber "de olhos fechados e dentes cerrados", procuraram obter bom vinho. De onde importá-lo? Certamente das regiões mais próximas, de onde seja possível trazer fàcilmente vinhos que se pudessem beber. As limitações dos transportes excluíam de antemão os países mediterrâneos, demasiado distanciados, e dos quais o vinho não poderia vir senão por meio de complicados e dispendiosos carretos através da Europa. Tais limitações obrigavam a que se recorresse aos países mais vizinhos, os da zona mediana; o abastecimento continuou a fazer-se - e muito mais abundantemente - nos vales do Reno, do Mosela, do Mosa, do Aisne e do Sena, de onde os vinhos chegavam fàcilmente, descendo êsses rios, aos lugares de consumo. Os países situados na costa do Mar do Norte, porém, encontraram centros de produção superiores nos vinhedos mais meridionais das costas do Oceano, o vinhedo de Aunis e o da Aquitânia; de onde o vinho podia chegar tão cômodamente por via aquática, pelo mar, é verdade, que as primeiras cruzadas haviam ensinado aos marinheiros inglêses e flamengos a percorrer de norte a sul.

Certos acontecimentos políticos desempenharam, então, um papel decisivo: em dezembro de 1154, Henrique II, Plantageneta, duque de Normandia e conde de Anjou, que se casara, havia dois 
anos, com Alienor, duquesa da Aquitânia, torna-se rei da Inglaterra, por morte de Estêvão de Blois. Constitui-se um imenso império atlântico, que abrange, ao mesmo tempo, as Ilhas Britânicas e as províncias setentrionais e ocidentais da França, banhadas pelo Oceano, desde a embocadura do Bresle à do Bidassoa. Regiões em que a vinha amadurece bem, e nas quais se fazem excelentes vinhos, - como o Aunis e o da Aquitânia, ao sul do Loire - são ligadas a regiões setentrionais de má vinicultura e a elas unidas pela fácil via marítima. Uma corrente de importação dos vinhos do Aunis e da Aquitânia para os países da Mancha e para a Inglaterra tendia a desenvolver-se por si só: desde meados do século XII, encontramse êsses vinhos em Flandres, onde a etapa da reexportação dos vinhos gascões é estabelecida em Damme, anteporto de Bruges, em 1180. A união política pessoal de parte dessas regiões atlânticas reforça essa corrente econômica natural em proporções inestimáveis. $\mathbf{E}$ os privilégios concedidos na Inglaterra aos comerciantes rocheleses e gascões, e, no Aunis e na Guyenne, aos comerciantes inglêses, aumentam-na principalmente em direção à Inglaterra.

As vicissitudes políticas, que tão fortemente influenciaram o estabelecimento dessas correntes comerciais, continuam a influir em seu desenvolvimento. O rei da França procura unir ao seu domínio os feudos continentais dos Plantagenetas, que Filipe Augusto declarou confiscados em 1202, e conquista-os uns após outros: Luiz VIII, em 1224, apodera-se definitivamente do Poitou e do Aunis. La Rochelle torna-se pôrto do domínio real francês. Luiz IX, porém, não consegue apoderar-se da Aquitânia que continua sendo a única possessão continental dos Plantagenetas, reis da Inglaterra. Dêsses acontecimentos resulta uma dissociação muito nítida das correntes comerciais que se haviam estabelecido no Atlântico: é apenas da Aquitânia que os inglêses vão importar quase que exclusivamente, daí por diante, os vinhos de que têm necessidade. A corrente comercial que se destina à Inglaterra não tem mais que uma única fonte: a Guyenne. Concentra-se, por três séculos, em um ponto de partida quase único: Bordéus, capital do ducado, banhada pelo Garona, por onde fàcilmente sobem os navios do mar.

Quanto ao vinhedo de Aunis, só conta, para a exportação, com as regiões dependentes da França situadas na Mancha e no Mar do Norte; os comerciantes flamengos continuam a vir abastecer-se tanto em La Rochelle como em Bordéus, podendo revender parte dêsses vinhos de Aunis na Inglaterra, e o desenvolvimento do seu comércio manifesta-se na imitação das Listas de Oleron pelas leis de Damme: o comércio de vinhos determina o direito marítimo do Oceano.

Ao mesmo tempo, o desenvolvimento, em París, do maior centro urbano do Ocidente, do qual a residência real, o crescimento da

- Universidade e a grande quantidade de comerciantes fazem um importante centro de consumo de vinhos de qualidade, levou os ne- 
gociantes de vinho a irem procurar mais para o sul êsses vinhos de qualidade. Um vinhedo se thes oferece naturalmente: é aquêle que, na orla e nas planícies interiores do Maciço Central, tem o nome geral de vinhedo de Borgonha; é principalmente ao vinhedo da Baixa Borgonha, o da região de Auxerre, de onde os tonéis chegam diretamente a París pelos vales do Yonne e do Sena, que êles se dirigem; mas quanto aos vinhos de alta qualidade, que parte de sua rica clientela deseja, fazem-nos vir da região de Saint- Pourçain-sur-Sioule, pelo Allier e pelo Loire, e por um ligeiro transporte por terra, entre o Loire e o Loing, afluente do Sena, ou da região de Beaune, pela mesma via, após um mais longo transporte por terra até Nevers.

Assim se estabeleceram, progressivamente, no decorrer do XII e XIII séculos, grandes correntes comerciais entre centros de produção de vinhos e de boa qualidade situados na zona vitícola mediana e os grandes centros de consumo da zona do Norte, onde a vinha se adapta mal. Foi a relativa proximidade dessas diverras regiões de produção e de consumo que determinou essas correntes e deixou de lado a região mediterrânea, demasiado longínqua. E' impressionante ver-se, como notou Dion, desenvolveremse êsses vinhedos de exportação nas proximidades das vias navegáveis que permitem a saída fácil dos vinhos, que os rios levam, fluindo em direcão aos centros de consumo ou aos portos de exportacão. O vinhedo aquitano ou gascão, por exemplo, só se desenvolve ao longo do Garona e de todos os seus afluentes: começa no Ariège, em Pamiers, no Tarn - em Albi, no Dordogne - no Passo de Gratusse, pontos a partir dos quais é possível a navegacão rio abaixo; os vinhos descem os rios até Bordéus ou Libourne, onde são embarcados em navios de mar. A possibilidade de exportação e a venda remunerada dela resultante levam os viticultores a cuidar da viticultura e da vinificacão a fim de obterem produtos que conservem o mercado e resistam à concorrência. E' essa a causa do constante esfôrço dos homens dessas regiões medianamente favoráveis à cultura da vinha no sentido de melhorar seus métodos e seus produtos; e foi êsse esfôrço; iniciado desde o século I de nossa éra, mas desenvolvido principalmente depois do século XI. nue produziu no Bordelês e na Borgonha - pois o terceiro vinhedo, o de Aunis, arruinado pela filoxera. cedeu, recentemente, o lugar às pastagens de Charentes - os vinhedos mais bem cuidados e a vinificação mais aperfeiçoada do mundo. Os viticultores do XII e XIII séculos esforçam-se por selecionar esvécies que melhor resistam ao frio e à umidade: aparam, escavam e cultivam as vinhas por três vêzes consecutivas, no fim do inverno e na primavera; podam cuidadosamente a vinha e prendem-na em escoras; fazem-na multiplicar-se por mergulhia; sabem quanto importa que as vasilhas de vinho permaneçam sempre repletas e por isso enchem completamente o tonel com vinho da mesma quali- 
dade; preservam os vinhos das variações atmosféricas. Mas, por falta do conhecimento de certas técnicas, como a depuração, e certos processos de conservação, como a garrafa de vidro, os vinhos que dêsse modo produzem, tanto na Gasconha como no Aunis e na Borgonha, são muito mais fracos que os dos antigos e não se conservam; consomem-nos desde a vindima, e, por vêzes, mesmo, antes da completa maturação, como agraço. Na Idade Média só se bebem os vinhos novos, os vinhos jovens do ano: um vinho de dezoito meses é considerado como passado, sem dúvida azedado, e vendido a preço vil. Nessas condições, não poderia haver produções particulares; os vinhos são de qualidade variável segundo as regiôes, e, em cada região, segundo o produtor, mas todos são, de acôrdo com nossos critérios, de produção corrente.

$* \quad *$

*

Esses característicos dominantes do grande comércio de vinhos, que assim se fixaram, aos poucos, do século XII ao século XIII, subsistem sem maiores alterações durante os dois últimos séculos da Idade Média.

E' possível delinear o quadro de conjunto dêsse grande comércio no século XIV.

$\mathrm{Na}$ bacia mediterrânea, tôda a orla oriental e meridional e o sul da Península Ibérica, que se encontram em região islâmica, deixaram de cultivar a vinha destinada à produção do vinho; parece que o comércio e o consumo do vinho se retiraram da Síria e da Palestina com os Cruzados; é, sem dúvida, para a colônia de comerciantes cristãos que alguns tonéis são ainda transportados de Marselha a Alexandria, nos séculos XIII e XIV. Em compensação, todos os países da orla setentrional e ocidental do Mediterrâneo cultivam a vinha e fazem vinho nas tradicionais condições de facilidade. A vinha cresce freqüentemente nas árvores, ou por entre outras culturas, sem maiores cuidados, e o vinho é feito simplesmente na prensa local. Essses vinhos, em seu conjunto, são consumidos no próprio local ou nas cidades vizinhas do campo em que foram feitos; como cada país mediterrâneo produz seu vinho, não há motivo algum para o desenvolvimento da exportação a grande distância. Esta só se faz com os vinhos particulares, que alcançam reputação mundial, em seguida à passagem de peregrinos ou de Cruzados, como os vinhos da região de Monemvasie, na Moréia, também, chamados vinhos de Malvasia, que, do mesmo modo que os vinhos de Creta, Chipre e Rodes, serviram, a princípio, para o abastecimento dos patrícios venezianos e, desde o século XIII, são muito estimados nos países do Norte; sua raridade faz com que sejam vendidos caro; são para lá exportados pelas gá'eras genovesas, venezianas, e depois, florentinas, no século XV; 
como, ainda, os vinhos do Vesúvio e da Campânia, importados em Florença pela rica burguesia; como também a vernaccia da região das Cinque-Terre, próxima a La Spezzia, que, por vêzes, se encontra na mesa pontifical; como o vinho moscatel de Languedoc, de Malgueil ou de Claira, que os acompanhava freqüentemente; como, finalmente, os vinhos de Rioja, exportados para Castela.

Na zona mediana, situada imediatamente ao norte da zona mediterrânea, três grandes vinhedos bem se definiram. O primeiro, mais que um vinhedo, é uma faixa setentrional de vinhedos que subsistem da embocadura do Loire, a oeste, à Baixa Áustria, a leste; abrange sucessivamente os vinhedos do Anjou, do Orléanais, da Ilha-de-França, do Soissonnais e do Laonnais, da Lorena, dá Alsácia e da Renânia, da Baviera e do Tirol. São vinhedos tradicionais que se mantêm melhorando sua prođução; vendem seus vinhos às regiões imediatamente vizinhas, que deixaram de cultivar a vinha; êsses vinhedos são misturados a outras culturas; reservamse-lhes as costas ensolaradas, onde, sôbre solos calcáreos a vinha cresce fàcilmente e a uva amadurece. Os mesmos apenas mantêm uma exportação regional.

O segundo grande vinhedo é constituído do conjunto Maciço Central - Borgonha - Jura. E' um vinhedo situado mais ao sul que o anterior, que produz vinhos de qualidade, entre os quais os que são, certamente, mais apreciados, na Idade Média: os vinhos de Saint-Pourçain-sur-Sioule, de Givry e mormente o de Beaune. Tais vinhos são exportados em larga escala, tanto para as regiões do Norte quanto para as do Sul, onde a situação do vinhedo, estabelecido em região de média altitude, que separa as bacias dos rios que divergem uns para a Mancha, outros para o Mediterrâneo, permite-lhes, igualmente, saída. $O$ fato de serem exportados tanto para o sul quanto para o norte, onde encontram estabelecidos vinhos locais dos vinhedos mediterrâneos e setentrionais, prova por si mesmo sua qualidade superior. Pelo Loire, Allier, Yonne, Sena, Armançon, Aube, atingem París, onde o desenvolvimento da côrte e dos palácios principescos lhes garante um mercado sempre crescente; não há sagração real em Reims, nem entrada de rei c $\because$ píncipe em París, sem que, em grande quantidade, sejam abertos tonéis de vinhos de Beaune e de Saint-Pourçain. Pelo Saône e pelo Ródano, chegam a Avinhão, onde à côrte pontifical consome anualmente cêrca de cem tonéis; os provedores de vinhos dos papas apreciam-nos tanto que enviam, cada outono, um comprador especializado, que, com a ajuda dos comissários de vinhos e degustadores locais, escolhe os vinhos destinados à mesa do papa, em Beaune e Givry. E Petrarca, em suas célebres invectivas, pretende que sejam os vinhos de Beuane que retêm em Avinhão o papa e os cardeais, a quem Pierre Bersuire chama, por sua vez, de "pássaros brancos de garganta larga de Avinhão, engolidores de vinhos". Esses humanistas, porém, não têm razão: quando, em 1367, Ur- 
bano V troca Avinhão por Roma, faz-se acompanhar de sessenta tonéis de vinho de Beaune, que lhe continua a ser enviado cada ano; ainda mais: esforça-se por obter em Roma vinhos da mesma qualidade que os do Ródano, plantando uma vinha, segundo os métodos do Avinhão, com cêpas importadas. Finalmente, quando, a partir de 1384, o duque de Borgonha se tornou conde de Flandres, e depois, progressivamente, senhor de todos os grandes feudos dos Países-Baixos, onde êle reside cada vez mais, o vinho de Borgonha encontra nessas regióes um novo e importante mercado, que a união política pessoal do ducado com êsses grandes feudos favorece consideràvelmente. $E$ ' o equivalente do que se passa entre a Aquitânia e a Inglaterra, e a fortuna para o vinhedo borgonhês que quisesse abusar disso: a fim de manter a qualidade, o duque legisla até mesmo sôbre as variedades de cêpas, proibindo aquelas cuja abundante produção é medíocre. Os vinhos de Beaune constituem um dos elementos do êxito de sua política; presenteia-os a todos aquêles a quem deseja cativar ou seduzir, quer se trate do papa ou dos padres do Concílio de Constança. Em sua nova expansão em direção ao norte, porém, os vinhos borgonheses se detiveram a certa distância do mar: tôda a zona costeira, Flandres, a Zelândia, a Holanda, era, desde o século XII abastecida de vinhos do Aunis e da Aquitânia; êstes resistiram vitoriosamente até nossos dias à invasão borgonhesa, que, ainda atualmente, permanece restrita à região walã.

O terceiro grande vinhedo é o do Aunis e da Aquitânia. O vinhedo do Aunis continua a abastecer de vinhos do Poitou, de La Rochelle e de Saint-Jean-d'Angély a maior parte das regiões da costa meridional do Canal da Mancha até a Holanda e as cidades hanseáticas, cujos comerciantes vêm procurá-los juntamente com o sal da baía de Bourgneuf ou de Brouage. Mas o mais interessante e também o mais importante é o vinhedo aquitano ou vinhedo gascão, que se estende ao longo do curso do Garona e de seus afluentes, e cuja exportação dos seus produtos para Flandres e mormente para a Inglaterra faz a fortuna de Bordéus. Os burgueses bordeleses, possuidores dos vinhedos do baixo vale do Garona, o atual Bordelês, receberam do rei da Inglaterra, duque de Aquitânia, o privilégio de só êles venderem seus vinhos após a vindima, no outono; os produtores da alta região, situada rio acima de Saint-Macaire, não podem enviar seus vinhos a Bordéus antes do Natal. Os burgueses de Bordéus têm, pois, a certeza de vender tôda a sua colheita; e, além disso, tiram importantes lucros da passagem dos vinhos da alta região por sua cidade. Cada ano, duas frotas de cêrca de duzentas velas vêm procurar os vinhos, uma imediatamente após a vindima, no outono, e a outra, após as tempestades hibernais, que impedem a navegação, na primavera; a primeira carrega, portanto, os vinhos dos burgueses, e a segunda, os da região alta. Essas frotas, compostas, no princípio do século XIV, de barcos flamengos, 
bretões, normandos, baioneses, castelhanos ou inglêses, são, cada vez mais, compostas exclusivamente de barcos inglêses, pelo menos no que se refere ao transporte direto para a Inglaterra, a partir do ato de navegação de Ricardo II (1381). O volume de vinhos por êles levado é considerável; as contas do impôsto recebido à passagem dos barcos carregados de vinho diante de Royan, à saída da Gironda, e as contas dos direitos alfandegários dos portos inglêses (Bristol, Southampton, Sandwich, Londres, Hull) permitem estimar-se em cêrca de 50.000 tonéis por ano, em média, a exportação de vinhos de Bordéus para a Inglaterra; avaliando-se o tonel em 900 litros, obtem-se perto de 450.000 hectolitros, isto é, mais da metade da atual exportação anual dos vinhos da França. Esse número é considerável, se se pensar que a população urbana da Inglaterra e dos países do Norte que, principalmente, consumia êsses vinhos era de cinco a dez vêzes menor que a de nossos dias. Tratava-se, porém, na Idade Média, de vinhos comuns, ao passo que atualmente a França exporta apenas vinhos de colheita de alto preço, que constituem um produto de luxo. O vinho era luxo sòmente para o inglês ou flamengo da Idade Média; era o melhor e quase que o único tônico ao qual podiam recorrer; por isso, tanto o inglês médio como o flamengo médio bebia, então, três ou quatro vêzes mais que o seu descendente do século XX. A importação de vinhos constituía em 1450 a têrça parte das importações inglêsas, ao passo que não chega à centésima, atualmente; equivalia, como cifra de negócios, à exportação de lã. Era êsse, portanto, um elemento muito importante do grande comércio mundial.

Mal sabemos'em que condições se fazia êsse comércio; ignoramos como eram financiadas as compras, como se associavam entre si, se é que o faziam, os compradores inglêses que vinham a Bordéus e os vendedores gascões que iam a Londres; gozavam, comumente, uns e outros, do direito de cidadania nas duas cidades. Conhecemos principalmente os revendedores da Inglaterra e dos paises do Norte: os revendedores atacadistas, os viniers, fazem parte, em tôdas as cidades, do mais poderoso patriciado; os revendedores varejistas, os taberneiros, constituem, por tôda a parte, uma das mais ativas profissões; êsse comércio de um produto de luxo importado em grandes quantidades enriquecia todos os que dêle se ocupavam; as próprias cidades auferiam importante parte de seus lucros: o tribunal sôbre os vinhos constituía um de seus principais recursos. O mesmo acontecia, aliás, nas cidades italianas.

A grande corrente comercial fixa formada pela exportação regular dos vinhos gascões para a Inglaterra acarretou tôda uma série de conseqüencias. $\mathrm{Na}$ ordem econômica, levou progressivamente os burgueses, certos de poderem vender tôda a sua colheita a preços remuneradores, a desenvolver cada vez mais a cultura da vinha no Bordelês, a ponto de desprezar a dos cereais: no século $\mathrm{XV}$, o Bordelês não mais produz cereais em quantidade suficiente 
para o seu consumo; os navios que vêm procurar os vinhos trazemThe cereais, lãs, tecidos e peixes secos da Inglaterra. E, ao que parece, a primeira região da Europa em que se pode verificar, desde a Idade Média, a tendência à monocultura .

E a riqueza que resultava, e que é ainda hoje comprovada pelos monumentos medievais de Bordéus, ligava de maneira muito intima a burguesia bordelesa à dominação política do rei da Inglaterra, duque da Aquitânia .

Por isso, quando, em 1451, o rei da França Carlos VII, realizando, dois séculos e meio após a tentativa de 1202, os projetos de Felipe Augusto, se apodera do ducado da Aquitânia, reunindo-o ao domínio real, o acontecimento aparece como capaz de provocar uma catástrofe econômica sem precedentes, de arruinar êsse florescente comércio, pois que a produção do vinhedo gascão não se pode desviar para o resto da França, abastecida por outros vinhedos. Os bordeleses, que se inquietavam pela sua fortuna, manifestam ao rei da Inglaterra lealdade ao mesmo tempo pura e interessada: conspiram com êle para expulsar o rei da França e restabelecer o anterior estado de coisas; conseguiram-no em 1452. Ora, Carlos VII reconquista duramente Bordéus e tôda a Aquitânia em 1453; isto constitui golpe muito violento dado ao comércio de vinhos com a Inglaterra, que se vê bruscamente reduzido à têrça parte do que era antes. Surpreendente, porém, é verificar-se que êle não desaparece completamente, e que não sòmente marinheiros bretões, mas até mesmo marinheiros inglêses continuam, em pleno período de hostilidades, a ir a Bordéus, a tal ponto era o comércio de vinhos essencial e lucrativo. O rei da França, aliás, não ousava proibir que os inglêses fôssem amiúde a Bordéus. Hesitava entre duas soluções igualmente perigosas: ou bem interditar aos inglêses a ida a Bordéus a fim de procurarem vinhos, o que arruinaria a cidade e acarretaria o perigo de nela suscitar, assim como na região vizinha, desordens e revoltas; ou bem arriscar-se a que navios inglêses que vinham em busca de vinhos desembarcassem, um dia, um novo exército inglês. Luiz XI, que tinha o senso agudo das realidades econômicas, encontrou a solução, impondo aos navios inglêses um contrôle militar muito severo, ao entrarem na Gironda. E desde que, pela paz de 1475, terminou a Guerra dos Cem Anos, a exportação do vinho gascão, por Bordéus, para a Inglaterra, recuperou os dois terços de sua anterior amplitude.

Essa grave crise, que de modo tão nítido revela as reações do elemento político sôbre o econômico e do econômico sôbre o político, mostra, ao mesmo tempo, a situação de um vinhedo do qual ainda não se tratou neste estudo: o vinhedo português, locaínzado à margem do Atlântico, em um clima em geral comparável, por causa da latitude, ao clima mediterrâneo, tão favorável à cultura da vinha. $O$ vinhedo português é tardio; foi plantado progressivamente no decorrer da reconquista do país pelos cristãos aos muçulmanos, 
a partir do XI século; só muito lentamente, sem dúvida, é que se desenvolveu, porquanto é vinho gascão e não vinho português que se vende em Sevilha, Córdova, Valença, logo que foram libertadas dos muçulmanos, no XIII século, antes de se formarem, aos poucos, - vinhedo andaluz e o levantino. Portugal acha-se admiràvelmente localizado para vender seu vinho à Inglaterra, com a qual mantém excelentes relações políticas desde o fim do século XIV; contitui o terceiro mercado de exportação dos tecidos inglêses, e os navios que levam tecidos poderiam voltar carregados de tonéis. Quando, porém, o vinhedo português se desenvolveu, o consumo inglês estava, por assim đizer, monopolizado pela viticultura gascã, sustentada por privilégios alfandegários que resultavam dos estreitos liames políticos existentes entre a Inglaterra e a Aquitânia. Nessas condições, o vinhedo português, por falta de importantes exportações, embora vendesse vinho aos flamengos e aos bretões, por vêzes por intermédio de comerciantes rocheleses, no século XIV, não se desenvolveu consideràvelmente. $\mathrm{E}$ quando sobreveio a ruptura política de 1451-1453, entre a Inglaterra e a Aquitânia, ocasião em que se lhe oferecia magnífica oportunidade de substituir o vinhedo gascão para o fornecimento de vinho à Inglaterra, não pôde fazê-lo porque the faltavam os meios para isso; sua produção era insuficiente. A história do vinhedo português é ainda mal conhecida; não se põe em dúvida a competência técnica dos portuguêses, pois nesse mesmo século XIV aclimataram com pleno êxito as variedades de cêpas de Malvasia na ilha da Madeira; mas a melhor prova do pequenc desenvolvimento dêsse vinhedo bem situado, mas que nasceu tardiamente, quando as principais correntes já estavam. bem estabelecidas, encontra-se no fato de que o mesmo foi incapaz de aproveitar a excepcional oportunidade que se the oferecia em 14511453. Um vinhedo e um regime de exportações não se improvisam de um ano para o outro, e a hábil política de Luiz XI restabeleceu a corrente tradicional Aquitânia-Inglaterra antes que os viticultores portuguêses tivessem tido tempo de conquistar um lugar no mercado ingiês.

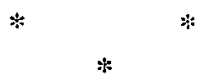

No fim da Idade Média, no século XVI, o quadro do grande comércio de vinho permanece, pois, em seus traços essenciais, o mesmo que se definira no século XII, no qual as trocas internacionais haviam recomeçado em larga escala.

A procura de vinho, para as necessidades físicas dos homens, que não têm mais que êsse tônico para sustentar-se, aumentou com a população no século XIII e mormente com o desenvolvimento das cidades nos séculos XIV e XV. Ora, os países do Norte, cujo grande progresso na Idade Média, assim como a conquista muçulmana da 
África e da Ásia Menor, atrai o centro de gravidade da cristandade para a Françá, não produzem naturalmente vinho de qualidade suficiente; é dessa discordância, desconhecida pela Antiguidade, entre os países produtores e os países consumidores que nasceu o grande comércio de vinhos. E' um fato novo da Idade Média, fato próprio a essa época: o comércio de vinho, na Idade Média, constitui um dos grandes comércios do mundo ocidental. E contribuiu, pela certeza da venda, para o desenvolvimento dos melhores vinhedos que se encontravam mais próximos dos países do Norte e a êles unidos por excelentes vias aquáticas, rios ou oceanos, e, conforme o caso, por liames políticos. Foi o comércio medieval de vinho que dêsse modo fêz a qualidade a fortuna dos grandes vinhedos franceses atuais, situados na zona mais próxima dos países do Norte.

Assim, no século XVI, na bacia mediterrânea, cada país bastou-se a si próprio; mesmo os vinhos de qualidade, importados nas grandes cidades, não vêm de longe: na Florença dos Médicis, consomem-se, além dos vinhos regionais, Trebbiano, vinhos doces da Sardenha, vernaccia, vinhos da Riviera e de Malvasia. Entre êsses vinhos doces de importação, o de Malvasia é o único de proveniência longinqua; no século $\mathrm{XV}$, foi objeto de ativa exportação para os paises do Norte, nas galeras italianas; depois que os portuguêses o implantaram na Madeira, porém, é o seu descendente, o madeira, que o substitui cada vez mais no mercado inglês: Falstaff, o grande bebedor no qual todos os franceses reconhecem o inglês tradicional da Idade Média, muito dado ao vinho, é acusado por Poins, na peça Henry IV, de Shakespeare, de haver vendido sua alma por uma taça de vinho da Madeira e uma asa de frango frio.

Os vinhedos da zona mais setentrional, que se estende do Anjou à Áustria, continuam a fornecer vinho para o consumo das regiões imediatamente vizinhas. E é para os vinhedos português, borgonhês e gascão que sempre se voltam os consumidores setentrionais . O vinhedo portugês, como vimos, pouco produzia. O vinhedo borgonhês acaba de garantir para si, graças às circunstâncias políticas, além do mercado parisiense, o magnífico mercado dos Países-Baixos interiores, que sempre conservou daí por diante: em París bebe-se mais borgonha que Bordéus, e em Liège, Namur, Lille, ainda se fazem, aos domingos, reunióes de amigos, para beber vinho de Borgonha em animadas assembléias, que, de maneira muito exata, continuam as compotaciones das velhas ghildas da Alta Idade Média. O principal vinhedo, porém, era ainda, não obstante as vicissitudes da política, o vinhedo gascão, que abastecia o mercado inglês, o dos Países-Baixos marítimos e o dos países do Báltico: Falstaff, ainda êle, gaba-se de poder conter na pança tôda a frota dos vinhos da Gasconha. E desde o século XVI, os burgueses das cidades flamengas e hanseáticas já são os melhores conhecedores do vinho de Bordéus, como ainda na atualidade. Mormente, graças a êsses estáveis mercados, fizeram os viticultores borgonheses e gascãos. 
desde o século XII, incomparáveis progressos técnicos, que os levaram a produzir vinhos de qualidade em condições naturais menos favoráveis que as da bacia mediterrânea. Tal adiantamento, mantiveram-no graças a tão antiga tradição de viticultura e vinificação cuidadosas. E' aos vinhateiros e adegueiros da Idade Média que o vinhedo de Bordéus e o de Borgonha devem, em grande parte, sua atual primazia mundial. Ainda no século XVIII, como nos melhores anos do século XIV, exportava Bordéus 60.000 tonéis anualmente.

Entretanto, êsse vinho do século XVI, êsse vinho da Idade Média não era o de hoje, e a ausência de qualquer tônico concorrente assegurava ao comércio de vinho considerável proeminência. Com o XVI século inicia-se novo período, em que, aos poucos, tanto o produto como as condições de seu comércio se transformam. E' no XVI século que aparece o álcool produzido pela distilação do vinho, mas que também se pode tirar de outras matérias orgânicas: o álcool não tarda a ser importado das colônias da América, sob a forma de rum. E' dêle que os marinheiros holandeses, que se tornaram os fretejadores do mar, carregam os navios para as necessidades da tripulação; e, aos poucos, é produzido em todos os países. $\mathrm{E}$ a aguardente, tônico mais forte sob menor volume, contitui o primeiro concorrente do vinho; vêm, depois, o café, o chá e os aperitivos, até que chegue a coca-cola. E' a partir do século XVI que se desenvolve a ciência da conservação dos vinhos, graças à garrafa de vidro. E' a partir do século XVIII que aparecerão os vinhos especiais, os vinhos de produção particular, que a técnica da depuração permite conservar por muito tempo e que são os vinhos de hoje. Tôdas essas novidades modificam completamente o comércio de vinho tal como êle se instituira e subsistira durante quatro séculos, na Idade Média. O grande aumento da população e o desenvolvimento industrial nos países do Norte correspondem, por isso, e, aparentemente, de modo paradoxal, a uma diminuição relativa considerável do papel desempenhado pelo vinho no grande comércio mundial. O vinho não é hoje, nesse grande comércio, mais que um produto de luxo, e é a uma tradição milenar e insubstituível, origem de sua qualidade, que os vinhos de Borgonha e de Bordéus devem o fato de haverem conservado um pequeno mercado mundial.

Assim, a Idade Média, em que șó se exportavam vinhos correntes do ano, em que o vinho era o único tônico que se conhecia na Europa, é o grande período da história do vinho; aquêle em que o seu consumo foi o maior, aquêle em que êle constituiu um dos produtos dominantes do comércio mundial.

\section{Y. RENOUARD}

Professor de História Medieval. Diretor da Faculdade de Letras de Bordéus. 